\title{
MAŁŻEŃSTWO I DZIEWICTWO WEDŁUG ŚW. METODEGO Z OLIMPU
}

Problematyka balzeństwa i rodziny w starożytności chrześcijańskiej, zwłaszcza w jej najwc seśniejszym okresie, powiazana jest ściśle z rozunieniem uziewictwa oznácajacego pewien wyższy stan doskonałości chrześcijańskiej. Stød też - jak wiadono nie znajlujemy u ojców Kościoła osobnych traktatów poświęconych rodzinie, podczas gdy nie brak bogatej literatury patrystycznej na temat dzieisictwa /wymieńny tu choćby dzieła Tertuliana, Cyprianá, Ambrozeggo/ ${ }^{1}$. Wíród przyczyn, warunkujzcych taki stan rzeczy, nalézy wymienić poglady rygorystyczno-enkratyczne, cieszace się duż popularności Ł w najwcześniejszym corześcijaństwie. Sprzyjało im nastawienie eschatologiczne pierwszych chrześcijan, żyjacych w klimacie oczekiwania rychłej paruzji Chrystusa, który jest jedynym oblubieńcem. Szerzeniu się poglądów rygorystycznych sprzyjala także konieczność zajęcia przez chrześcijan postawy antagonistycznej do świata pográskiego, a zwłaszcza do rozwiązłości moralnej, która ten świat sobą reprezentorał. Nie bez znaczenia także była infiltracja kultur orientalnych, zwłaszcza dualizmu. Próbę pobieżnego przeglądu wyżej wymienionych przyczyn podjął M.Michalski w "Antologii literatury patrystycznej"2。

Stąd też zaciowane przekazy ojców Kościoła, zajmujące się problematylriz małżeństwa i rodziny, należy odnajdywać w różnych ich dziełach, zwłaszcza w homiliach, komentarzach, listach, a także traktatach o dziewictwie ${ }^{3}$. Wśsód tych ostatnich wymienić

1 Por. Tertullianus, De exhortatione castitatis, CCL 2,1015-1035; Cyprianus, De habitu virginum, CSEL 3,1, 185-205; Ambrosius, De virginibus, PL 16, 197-244, De institutione virginis PL 16,319-348.

2 Por. M.Michalski, Antologia literatury patrystycznej, t.1, Warszawa $1975,426-429$.

3 Wykaz dzieł ojców Kościoła, w których poruszone są niektóre aspekty życia rodzinnego podaje ks. S.Longosz, kodzina wczesnochrześcijańska i jej zadania w nauczaniu św.Bazylego Wielkiego, iTK 28/1981/ z.4, 150, n.2. 
moźna dzieło powstałe pod koniec III w., stosunkowo mało znanego autora - sw. Metodego z 0limpu, noszące tytuł: "Symposion" "Uczta"4. Zarówno tytuł, jak 1 układ dzieła, wskazuja, ze autor naśladoval platona, a z treści dzieła mozemy wywnioskować, $1 z$ jest takze jego zwolennikiem. Pomljamy tutaj analize formy literackiej dzieła Metodego 5 . Główny wydźwiek "Uczty" - to zachęta do dzlewictwa. Autor niewąpliwie uwaźa, ze dziewictwo jest stanem wyzszym od małzęństwa. Równocześnie jednak pogląd ten usiłuje zrównowazyć 1 pogodzić z poglądem o świętośct 1 wznlosłości stanu małzeńskiego. Stąd dzieło jego posiada kapitalne znaczente dla pogłębienia problematyki małzeństwa we wczesnym chrześcjjaństwie. Przedstawiona wim jest rzeczywista dyskusja na temat dzlewictwa 1 mazzeństwa, która toczy dziesiec dziewic.

Metody jest millenarystą. Uzasadnienie wyższości dziewictwa nad mazzenstrem vidzi w etapach rozwoju ludzkości. W "Uczcie" przedstawione sa one $w$ mowie pierwszej z dyskutantek - Marce111, która stawia sobie za cel sławiente dzienictwa ${ }^{6}$.

Plerwszy etap rozwoju ludzkosel to - wg blskupa 01impu okres, wtórym małżenstwo żawierane było między rodzeństwem ${ }^{7}$. Autor nasz uwaza, ze od czasów Abrahama zaniechano pozycia z wasnymi siostrami 1 zaczeto brac za zony obce kobiety, rozpoczynajac - ten sposób drugl etap rozwoju ludzkośc1, który cechuje wielozén stro ${ }^{8}$. Swięty Biskup próbuje usprawiedliwie ten stan rzeczy, przedstawiając Boga jako Pedagoga, który zezwala naszym przodkom na teo go typu pozycie.

"Swlat bowiem, gdy nie napezniali go jeszcze ludzle, byz niczym małe dziecko, Iudzkośc musiala wzrosnąé

4 Symposion e peri agnelas, ed. H.Musur1110 Méthode d'olympe, Le Banquet. Introduction et texte critique par H.Musurillo, traduction et notes V.H.Debidour, Paris 1963, SCh 95/, t tum.S.KaIInk owski/Sw.Metody z Olimpu, Uczta, Wstep 1 opracowanteks.E. Stanula, Warszawa 1980/, PSP 24, 27-108.

5 Zagadnienie to omawla H.Musuril10 we wstępie do swego wylanla, SCh 95,30-38, a takze E.Stanula we mstepie do polskiego przeKładu, PSP 24, 10-11.

6 Symposion I 1-5, SCh 95,52-68, PSP 24,30-35.

7 Symposion I 2, SCh 95,56-58, PSP 24, 32 .

8 Symposion I 3 , SCh $95,60-62$, PSP $24,32-33$. 
w liczbie, a świat dzięki zastosowaniu takich środków mógł dojść jaik gdyby do męskiego wieku. Kiedy jednak ziemia zaludniła się od końca do końca i gdy ludzkość nieskończenie się pomnożyła, wówczas ßóg już nie pozwalał ludziom trwać przy dawnych obyczajach, lecz baczył na to, by je powoli zmieniali i starali siż zbliżać coraz bardziej do nieba tak długo, aź krocząc ku najwyższej i najważniejszej nauce, ku dziewictwu, dojdaz do doskonałości"9.

Trzeci etap rozwoju ludzkości to okres małżeństw monogamicznycł. Zdaniem naszego autora rozpoczą się on od czasów prorockich i oznacza wzrost świadomości etycznej od unikania cudzołóstwa do osiągnięcia panowania nad sobą 10 . Stąd już tylko krok, aby Iudzkość osiągnęła następny, czwarty etap rozwoju, jakim jest dziewictwo, które autor uważa za pewnego przewodnika do życia nieśmiertelnego, do osiagnięcia apokatastasis ${ }^{11}$. Nazywa je szczytowym i szczęśliwym stylem życia, bo ono "wynosi do równości z Bogiem tego, kto jelposiada i kto został wtajemniczony w jego nieskalane misteria"12. W rzeczywistości dziewictwo, to także zaślubiny, zaślubiny $z$ Boskim oblubieńcem ${ }^{13}$. Na etapie tym, chociaż preferowane jest dziewictwo, to jednak nie jest deprecjonowane małzeństwo. Jedna $z$ dyskutantek $w$ "Uczcie" - Procylla stwierdza wyraźnie:

"Niechaj jednak nikt nie przypuszcza, że pozostała rzesza wierzacych podlega odrzuceniu, i nie rozumiejazc, że będą gminy, rody i stany "zgodnie z wiaraz każdego"/hz 12,6/, niech nie sądzi, że tylko my, dziewice, jesteśny wprowadzane, aby otrzymać to, co obiecano. To właśnie opisuje także Paweł, mówiąc: "Inna jest chwała słońca, a inna ksiezzyca i gwiazd;

9 Symposion I 2, SCh 95,58, PSP 24,32。W wypowiedzi tej uderza podobieństwo do koncepcji Boga jako Pedagoga, którą przedstawia św.Ireneusz w "Adversus haereses", ale problem zależności Metodego od Ireneusza stanowi osobne zagadnienie.

10 Symposion I 3, SCh 95,60-62, PSP 24,32-33.

11 Por. Symposion IV 2, SCh 95, 128-132, PSP 24,53.

12 Symposion VIII 1, SCh 95,202, PSP 24,72. Chwałz dziewictwa opiewa także hymn Tekli, którego refren brzmi /SCh 95,310, PSP 24,101/: "Dla ciebie żyję w czystościli dzierżąc świetliste pochodnie/wychodze ci na spotkanie,lo oblubieńczel"

13 Por. Symposion VII 1, SCh 95, 182, PSP 24,67. Por. także Symposion VII 3, SCh 95, 186, PSP 24,68: "Zatem tylko te dusze [tj. święty orszak dziewic]' Słowo nazywa swa wybrana i prawowita oblubienicą". 
gwiazda bowiem różni się od gwiazdy chwałą. Pouobnie też $i$ zmartwychwstanie umarłych" $/ 1$ Kor $15,41-42 /^{14}$.

Swoją pełnię rozwoju ludzkość osiłgnnie dopiero na piątym etapie, po zmartwychwstaniu ciał, kiedy ludzie "już wiecej żenić się nie będą, ani za mąż wychodzić"/Mt 22,30/.

Aby wykazać, że małżeństwo, choć jest niższym stanem doskonałości chrześcijańskiej, to jednak jest potrzebne i przez Boga zamierzone, autor nasz używa kilku argumentów. Zawarte sa one głównie w przemówieniu drugiej z dyskutantek - Teofili, która zwraca uwage pozostałym na wzniosłość i świętość stanu małżeńskiego. Według nauki Metodego, stopniowe wznoszenie się ludzkości do dziewictwa nie może oznaczać całkowitego zaniechania prokreacji, świat bowiem ciągle jeszcze buduje się, a nakaz Księgi Rodzaju: "iośnijcie i rozmnażajcie się" / Rdz 1,28/ jest nadal aktualny ${ }^{15}$. Skoro "Bóg nadal pracuje modelując świat"16, to jest rzoczą oczywistą, że "człowiek musi jeszcze współdziałać przy tworzeniu obrazu Boga"17. Autor wskazuje, że poczęcie nowego człowieka w akcie małżeńskim jest ogarnięte tajemniczą moca samego Stworzyciela, stąd też byłoby rzecza co najmniej dziwnaz, a nawet zuchwała "odczuwanie wstrętu do prokreacji, skoro nawet Wszechmogazcy nie wstydzi się przykładać do niej swych nieskazitelnych rąk"18.

Z kolei Metody podkreśla oczywisty fakt, iź pokolenie świętych nie może sį wyczerpać na obecnej generacji. Także po nas musi nastąpić wielu jeszcze męczenników i świętych, którzy po prostu muszą się narodzić. Argument ten autor nasz wzmacria ostro sformułowanym pytaniem:

\footnotetext{
"Czyż zatem nie jest głupotą odrzucanie stosunków małżeńskich, jeśli oczekujemy, że i po nas będą istnieć świadk owie wiary/martyres/ i ludzie, którzy przeciwstawia sie złemu duchowi?"19
}

Ojciec Kościoła stawia jako pewnik twierdzenie, iż poczęcie pojedynczego człowieka jest wynikien zamysłu Bożego. Akt prokreacji nie

14 Symposion VII $3, \operatorname{SCh} 95,184, \operatorname{PSP} 24,68$.

15 Por. Symposion II $1, \operatorname{SCh} 95,70, \operatorname{PSP} 24,35$.

16 Symposion II 1, SCh 95,68, PSP $24,35$.

17 Symposion II 1, SCh $95,70, \operatorname{PSP} 24,35$.

18 Symposion II $2, \operatorname{SCh} 95,72, \operatorname{PSP} 24,36$.

19 Tanże. 
dokonałby się bez współdziałania Bożego, natura sama z siebie byłaby do tego niezdolna ${ }^{20}$. Biskup olimpu uzasadnia to w formie prostych pytań:
"Któż bowiem utwardził miękką substancję kośċi? Kto spoił giętkie członki tak, żeby za pomocą mięśni napinały się i kurczyły w stawach?... Kimże jest ten, kto sie troszczy, żeby zarodek umieszczony wewnątrz ciała matki nie udusił się w wilgoci i ciasnocie? .... Kto, jeśli nie jedyny I najlepszy Twórca, który modelując jak wosk wilgotne i maleńkie nasionka w kobiecym łonie wytworzył nas jako swój najrozumniejszy obraz i uczynił ożywiony- mi ludźmi?"21

Autor nasz jest świadomy, że Bóg może kierować procesami rozrodczości poprzez ustanowione przez siebie prawa biologii, obowiązujące w naturze, jednakże z całą mocą podkreśla, że dusza człowieka pochodzi bezpośrednio od Boga:

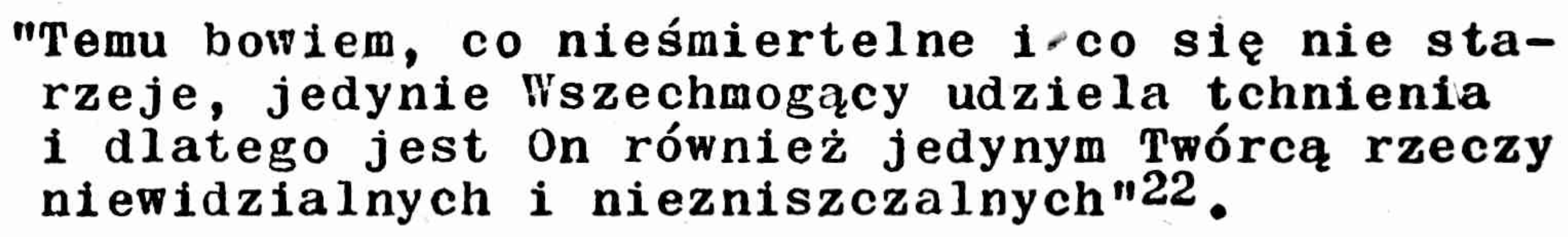

Tak więc z racji duszy nieśmiertelnej każdy człowiek mieści sie w planach Bożych, jest wynikiem zamysłu Bożego. Ten wchodzący na grunt personalizmu chrześcijańskiego wniosek nie zostaje w zadnym stopniu pomniejszony poprzez fakt, że sa dzieci, które rodza się na skutek cudzołóstwa. Metody podejmuje także ten problem w swoim dziele, nadając mu formę zaskakującego pytania: czy jest możliwe, aby owoce cudzołóstwa powstawały przy aprobacie Boźjej ${ }^{23}$ Odpowiedzi na to pytanie udziela posługując się niezwykle oryginalnym porównaniem ${ }^{24}$. Kaźe sobie wyobrazić dom, którego drzwi znajdują się w wysokich górach, a on sam sięga głęboko w dół. W tylnej cz̨ści jest zaokrąglony i posiada wiele okien. Wewnątrz

20 Por. Symposion II 6, SCh 95,82, PSP 24, 39 .

21 Tamże.

22 Symposion II $7, \mathrm{SCh} 95,84$, PSP 24,40 .

23 Por. Symposion II 3, SCh 95,76, PSP 24, 37.

24 Por. Symposion II 4-5, SCh 95,76-80, PSP 24, 37-39. 
domu siedzi artysta, który tworzy posagi z gliny dostarczanej mu z zewnatrz przez otwory w tylnej ścianie od wielu ludzi, którzy jednak artysty nie widza. Każemu z ludzi przydzielono jeden otwór. Artysta wewnaztrz odbiera glinq, modelujłc ją, a po upływie kilku miesięcy przez ten sam otwór oddaje ja znowu ludziom. Ma polecenie, aby każdą glinę obrabiać jednakowo, nawet taką, którą ktoś umieścił w otworze stanowiącym cudza własność, "materiał bowiea nie popełnił żadnego wykroczenia i dlatego trzeba go modelować i kształtować jako coś niewinnegon' ${ }^{25}$. Przestępca jest ten, kto umieścil go w cudzym otworze; glina nie ponosi żadnej winy. Autor sam natychmiast wyjaśnia sens tego obrazu: dom - to natura naszych narodzin, drzwi w wysokich górach - to zesłanie duszy do ciala, otwory - to płeć niewieścia, artysta - to twórcza moc Boża, dostawcy gliny - to męźczyźni, którzy powodowani "pragnieniem posiadania potomstwa składaja w naturalnych kanalikach kobiecych nasienie, jak glinę w otworach"26. Jeśli wskutek braku powściągliwości zbliżyi się do obcego otworu, to jednak "nie należy sądzić, że nasienie, które [... ] uczestniczy w Boskim dziedzictwie stwórczej potęg1, jest odpowiedzialne za podniety pożądliwości"27. Tak więc każdy człowiek, także poczęty w nielegalnym związku mieści się według Metodego w zamysłach Bożych.

\footnotetext{
"Pismo bow dem nie ódarcza wi ną nasienia, lecz obwinia tego, kto w cudzołożnych uściskach za cenę chwilowej przyjemości jak dzierzawca bezwstydnie rzuca wasne ziarno do cudzej gleby" 28 .
}

Wszystkie przytoczone powyżej argumenty ukazuja małżeństwo jako stan konieczny $w$ życiu ludzkim i uświęcony przez Boga. Biskup Olimpu sam podsuwa konkluzję:

3tokolwiek bowiem gruntownie i trzeźwo zastanowi sie nad naturalnymi sprawami ludzkimi, ten musi dojść do przekonania, ze chó́ dziewictwo jest bar-

25 Symposion II $4, \operatorname{SCh} 95,78, \operatorname{PSP} 24,38$.

26 Symposion II 5, SCh 95,80, PSP 24,38 .

27 Tanże.

28 Syroposion II $4, \operatorname{SCh} 95,76, \operatorname{PSP} 24,37$. 
dziej chwalebne i czcigodne, to jednak nie mozna tym

samym pogardzać małżeństwem i rodzenien dzieci" 29 .

Autor "Uczty" jest realista. Wie, że niemożliwe jest, aby wszyscy ludzie praktykowali dziewictwo oraz - cowiecej - jest świadomy, że wszyscy ludzie nie sá do tego predysponowani ${ }^{30}$. Wychwala dziewictwo, ale równocześnie poucza, że "praktykowanie dziewictwa jest darem bożym"31. W oparciu zaś o św. Pawła/1 Kor 7,37-38/ stwierdza:
"ten, kto potrafi i stara sie "zachować w dziewictwie" swoje ciało "robi lepiej" kto natomiast nie potrafi tego, lecz legalnie $i$ bez popełniania podstępnych de- prawacji zawiera małzeństwo, ten "robi dobrze"32.

Ciągle obecna i wyraźna w Kościele tensja między zrywami do szczytów doskonałości a życiem secundum naturam odczuwalna była zarówno w starożytności chrześcijańskiej, jak i odczuwalna jest wspó cześnie. Autor "Uczty" - Metody z olimpu przypomina chyba nie tylko starożytnym chrześcijanom, że Kościół, to ukwiecona, kolorowa ląka "uwieńczona różnobarwnie nie tylko kwiatem dziewictwa, lecz również kwiatami rodzicielstwa i powściągliwości"33.

\section{Ks. Bogdan Częsz - Poznań}

29 Symposion II 7, SCh 95,8 /przekład autora artykułu/, por. PSP 24, 40.

30 Por. Symposion II 7, SCh 95,86, a szczególnie stwierdzenie w Symposion III 11, SCh 95,114, PSP 24,48: "... rozumiejac słabość i podniety pociagajace ku stosunkom cielesnym ludzi mniej opanowanych, pozwolił przecież [św. Paweł] $/ 1$ Kor $7,5 /$, aby ci, którzy nad ciałem nie potrafiá zapanować, łaczyli się razem $z$ wasnymi współmałżonkami, niżby mieli popaść w rozpustę i szpetnie się wykoleić". To samo rozumowanie zastosował Metody do ludzi owdowiałych, przypominajac za św. Pawłeın /1 Kor 7,89/ w Symposion III 12, SCh 95,118, PSP 24,49: "... lepiej jest, żeby człowiek, który był mężem jednej kobiety, pozostał później sam, jak i on [św. Paweł]. Gdyby to jednak było dla kogoś niewykonalne ze wzgledu na wewnętrzny płomien i bujny rozkwit sił cielesnych [...] powtórne małżenstwo ... [jest] lepsze od płomie-
nia".

31 Symposion III 14, SCh 95,124, PSP 24,51.

32 Symposion III 14, SCh 95,124, PSP 24,52.

33 Symposion II 7 , SCh 95,86 , PSP 24, 41 . 


\section{JUNGFRAULICHKEIT UND EHE BEI METHODIUS VON OLYMPOS} /Zusammenfassung/

Methodius von 0lympos stellt in seinem Werk "Symposium" echte Diskussion zum Theina der Jungfraulichkeit und der Ehe dar. Indem er sich fur den Vorrang der Jungfralulichkeit erklart, lehrt er zugleich, daB die Ehe auch notig und von Gott geplant 1st. Zur Bestutigung dessen bringt er folgende Argumente vor: 1. die Notwendigkeit der Lebensentwicklug, 2. die Notwendigkeit der Geburt neuer Heiligen und wartyrer, 3. die Notwendigkeit der Mitwirkung mit Gott im Werk der Schøpfung Gott gibt jedem Menschen unsterbliche Seele und deshaib ist der Mensch auch der, der in einem Ehebruch geboren wurde, in Gottes Planen enthalten. Die Ehe ist also ein von Gott geheiligter Stand und der, der die Ehe schlieBt - "handelt richtig" $/ 1$ Kor $7,38 /$. 